\title{
Pengaruh Penambahan Eceng Gondok dan Limbah Cair Pengolahan Tahu Pada Produksi Biogas Terhadap Kualitas Fisik dan Kimia Sludge

\author{
Ludfia Windyasmara ${ }^{1}$, Kunty Novi Gamayanti \\ 1)Program Studi Peternakan, Fakultas Pertanian, Univet Bantara Sukoharjo, \\ Jl. Letjen Sujono Humardani No. 1 Jombor Sukoharjo, Kode pos 57512, \\ Telp.(0271)593156, Fax. (0271) 591065, Email : windyasmaraludfia@gmail.com
}

\begin{abstract}
Abstrak
Penelitian ini bertujuan untuk mengetahui kandungan pupuk organik dari Sludge biogas dengan bahan dasar feses sapi dengan penambahan eceng gondok (Eichornia crassipes) yang berbeda dan penggunaan limbah cair pengolahan tahu sebagai pengencer. Penelitian ini terdiri dari tiga perlakuan untuk perlakuan control $(\mathrm{P} 0)$, perlakuan pertama (P1) dan perlakuan kedua (P2), dengan perbandingan eceng gondok $0 \%, 2,5 \%$ dan $5 \%$. Parameter yang diamati meliputi $\mathrm{pH}$ Sludge, temperatur Sludge, temperature dan kelembaban lingkungan, analisis kadar air, bahan organik, N, P dan K. Data yang diperoleh dihitung dengan analisis variansi rancangan acak lengkap pola searah dan apabila menunjukkan perbedaan dilanjutkan uji beda mean Duncan's New Multiple Range Test. Hasil penelitian menunjukkan bahwa perlakuan perbedaan komposisi eceng gondok mempunyai pengaruh yang tidak nyata $(\mathrm{P}>0,05)$ terhadap $\mathrm{pH}$ Sludge, temperatur Sludge, temperature dan kelembaban lingkungan, analisis kadar air, bahan organiK, N, P dan K. Kandungan $\mathrm{N}, \mathrm{P}$ dan $\mathrm{K}$ menunjukkan kecenderungan meningkat dengan meningkatnya volume eceng gondok. Hasil rata-rata $\mathrm{N}, \mathrm{P}, \mathrm{K}, \mathrm{C} / \mathrm{N}$ rasio, BOD dan COD Sludge adalah 0,72 $\pm 0,57$ (P0), 0,87 $\pm 0,78(\mathrm{P} 1), 0,85 \pm 0,25$ (P2) rata-rata kadar $N, 0,25 \pm 0,14(\mathrm{P} 0), 0,24 \pm 0,22(\mathrm{P} 1), 0,38 \pm 0,32(\mathrm{P} 2)$ rata-rata kadar $\mathrm{P}, 0,36 \pm 0,11(\mathrm{P} 0)$, $0,44 \pm 0,14(\mathrm{P} 1), 0,63 \pm 0,32$ (P2) rata-rata kadar K. Kesimpulan yang dapat digunakan sebagai sumber bahan baku biogas menghasilkan pupuk organik yang dapat membantu mengembalikan kondisi kesuburan tanah.
\end{abstract}

Kata kunci: Feses sapi, Eceng gondok (Eichornia crassipes), Biogas, Pupuk organic

\section{PENDAHULUAN}

Pada industri pembuatan tahu, limbah cair yang dihasilkan adalah cairan kental yang terpisah dari gumpalan tahu yang disebut air dadih. Cairan ini mengandung kadar protein yang tinggi dan dapat segera terurai. Limbah cair ini sering dibuang langsung tanpa pengolahan terlebih dahulu sehingga menghasilkan bau busuk dan mencemari sungai.

Pencemaran sungai yang saat ini sering terjadi, bukan hanya berasal dari limbah industri tetapi dari gulma air yang tumbuh tidak terkendali, salah satunya adalah eceng gondok. Eceng gondok cepat beranak pinak dan akar serabutnya dapat merambah ke mana-mana. Tanaman air ini berpotensi menguasai dan memonopoli lahan serta menyingkirkan tanaman lain. Oksigen pun dapat direbutnya hingga mematikan ikan-ikan yang hidup di bawahnya (Don WS, et al., 2000).

Berdasarkan kondisi yang demikian maka perlu adanya langkah inovatif dalam menangani masalah limbah agar dapat lebih baik sehingga masalah pencemaran lingkungan dapat diatasi. Salah satu caranya dengan membuat instalasi biogas meskipun dengan model sederhana dan sentra pengolahan pupuk organik padat dan cair (Sludge). Pembuatan instalasi biogas dan pembuatan pupuk organik tersebut akan dapat memberikan banyak keuntungan yaitu, dapat teratasinya masalah pencemaran lingkungan akibat adanya limbah usaha, kecukupan energi untuk masyarakat terutama di pedesaan dapat dijamin yaitu dengan menggunakan energi alternatif yang relatif murah, ramah lingkungan, mudah diperoleh, dan dapat diperbaharui, serta 
dapat mendatangkan keuntungan yaitu pengolahan pupuk organik padat dan cair (Sludge) serta hasil fermentasi biodigester yang berupa gas methan.

Biogas adalah campuran gas yang dihasilkan oleh bakteri metanogenik yang terjadi pada material-material yang dapat terurai secara alami dalam kondisi anaerobik. Pada umumnya biogas terdiri atas gas metana (CH4) 50 sampai $70 \%$, gas karbondioksida (CO2) 30 sampai $40 \%$, hidrogen (H2) 5 sampai $10 \%$ dan gas-gas lainnya dalam jumlah yang sedikit (Wahyuni, 2008).

Sludge adalah limbah keluaran berupa lumpur dari lubang pengeluaran digester setelah mengalami proses fermentasi oleh bakteri metana dalam kondisi anaerobik. Setelah ekstraksi biogas (energi), Sludge dari digester sebagai produk samping dari sistem pencernaan secara aerobik. Kondisi ini, dapat dikatakan manur dalam keadaan stabil dan bebas patogen serta dapat dipergunakan untuk memperbaiki kesuburan tanah dan meningkatkan produksi tanaman (Wahyuni, 2008)

Sludge sisa fermentasi biogas merupakan pupuk yang siap pakai dan sangat baik untuk kesuburan tanah. Menurut Supriyanto (2001), Sludge kotoran sapi mengandung 1,8-2,4\% nitrogen, $1,0-1,2 \%$ fosfor (P205), 0,6-0,8\% potasium (K20) dan 50$75 \%$ bahan organik. Pupuk organik tesebut cukup lengkap sebagai sumber nutrisi bagi tanaman.

Penelitian ini bertujuan untuk mengetahui pengaruh penambahan eceng gondok (Eichornia crassipes) dan limbah cair pengolahan tahu terhadap kualitas unsur hara makro primer Sludge digester gas bio.

\section{METODE PENELITIAN}

Pelaksanaan penelitian dilakukan dengan menggunakan 5 unit biodigester sistem aliran kontinyu atau mengalir (continuos flow). Penelitian ini terdiri dari tiga perlakuan untuk perlakuan control (P0), perlakuan pertama (P1) dan perlakuan kedua (P2), dengan perbandingan eceng gondok $0 \%, 2,5 \%$ dan $5 \%$. Parameter yang diamati meliputi $\mathrm{pH}$ Sludge, temperatur Sludge, temperature dan kelembaban lingkungan, analisis kadar air, bahan organic, $\mathrm{N}, \mathrm{P}, \mathrm{K}, \mathrm{C} / \mathrm{N}$ rasio, $\mathrm{BOD}$ (Biochemical Oxygen Demand) dan COD (Chemical Oxygen Demand). Data yang diperoleh dihitung dengan analisis variansi rancangan acak lengkap pola searah dan apabila menunjukkan perbedaan dilanjutkan uji beda mean Duncan's New Multiple Range Test.

\section{HASIL DAN PEMBAHASAN}

\section{Temperatur Sludge}

Tabel 1. Rata-rata temperatur sludge $\left({ }^{0} \mathrm{C}\right)$

\begin{tabular}{cccc}
\hline Ulangan & \multicolumn{3}{c}{ Perlakuan } \\
\cline { 2 - 4 } & $\mathrm{P} 0$ & $\mathrm{P} 1$ & $\mathrm{P} 2$ \\
\hline I & 26,22 & 25,97 & 26,17 \\
II & 26,87 & 25,91 & 25,84 \\
III & 27,61 & 27,36 & 27,43 \\
\hline Rata- & $26,9 \pm 1,47^{\mathrm{a}}$ & $26,41 \pm 0,81^{\mathrm{a}}$ & $26,48 \pm 1,07^{0}$ \\
rata & & \\
\hline P0= 0\% eceng gondok, $\mathrm{P} 1=2,5 \%$ eceng gondok, \\
$\mathrm{P} 2=5 \%$ eceng gondok
\end{tabular}

Berdasarkan tabel 1. rata-rata temperatur Sludge pada penelitian ini lebih rendah dibandingkan temperatur optimal, karena penelitian dilakukan pada musim penghujan dengan rata-rata temperatur udara sekitar $26,59^{\circ} \mathrm{C}$, hal ini disebabkan pula karena mikrobia yang bekerja pada waktu digesti anaerobik tersebut berada pada temperatur mesofilik yaitu 20 sampai $45^{\circ} \mathrm{C}$. Situasi tersebut tidak banyak membantu untuk meningkatkan temperatur Sludge mencapai temperatur optimal.

Temperatur merupakan cermin dari aktivitas mikroorganisme di dalam Sludge, semakin tinggi temperatur maka aktivitas mikroorganisme juga semakin meningkat. Menurut Kaparaju dan Angelidaki (2006), pada temperatur $55^{\circ} \mathrm{C}$ jumlah Methanosarcinaceae pada permukaan Sludge mencapai 70 sampai $100 \%$ lebih banyak dari pada di lapisan bawah atau di lapisan tengah. Pada temperatur $10^{\circ} \mathrm{C}$ jumlah Methanosarcinaceae pada lapisan permukaan dan lapisan bawah Sludge mencapai $30-50 \%$. 


\section{Derajat Keasaman (pH) Sludge}

Tabel 2. Rata-rata Derajat Keasaman $(\mathrm{pH})$ sludge

\begin{tabular}{cccc}
\hline \multicolumn{3}{c}{ sludge } \\
\cline { 2 - 4 } & $\mathrm{P} 0$ & $\mathrm{P} 1$ & $\mathrm{P} 2$ \\
\hline I & 7,01 & 7,06 & 6,99 \\
II & 7,29 & 7,04 & 7,14 \\
III & 7,22 & 6,94 & 6,97 \\
\hline Rata- & $7,17 \pm 0,97^{\mathrm{a}}$ & $7,01 \pm 0,75^{\mathrm{a}}$ & $7,03 \pm 0,76^{\mathrm{a}}$ \\
rata & \multicolumn{3}{|}{} \\
\hline P0= 0\% eceng gondok, $\mathrm{P} 1=2,5 \%$ eceng gondok, \\
P2= 5\% eceng gondok
\end{tabular}

Derajat keasaman $(\mathrm{pH})$ hasil penelitian pengamatan setiap hari dapat dilihat pada tabel 2. Derajat $\mathrm{pH}$ tersebut masih termasuk netral. Aktivitas bakteri fermentatif mencapai optimal pada suasana $\mathrm{pH}$ netral yaitu 7,0 (Kirby, 1983). Menurut Sihombing (1997), setelah beberapa hari pencernaan (fermentasi) berlangsung bakteri metanogenik berangsur-angsur makin aktif sampai tercapai $\mathrm{pH}$ optimal atau netral. Menurut Sutanto (2005), keasaman $(\mathrm{pH})$ harus masuk dalam kriteria kualitas pupuk organik, berkisar netral, $\mathrm{pH}$ 6,5-7,5. Bila dibandingkan hasil penelitian yang diperoleh dengan literatur yang ada maka hasil penelitian masih berada pada kisaran normal.

Temperatur Lingkungan dan Kelembaban Udara

Tabel 3. Rata-rata Temperatur Lingkungan $\left({ }^{\circ} \mathrm{C}\right)$ dan Kelembaban Udara (\%)

\begin{tabular}{ccc}
\hline \hline Ulangan & $\begin{array}{c}\text { Temperatur } \\
\text { Lingkungan }\end{array}$ & $\begin{array}{l}\text { Kelembaban } \\
\text { Udara }\end{array}$ \\
\hline I & 26,28 & 78,13 \\
II & 27,11 & 78,13 \\
III & 28,13 & 77,47 \\
\hline Rata-rata & $27,17 \pm 0,56$ & $77,91 \pm 3,64$ \\
\hline
\end{tabular}

Data temperatur udara dan kelembaban udara dapat dilihat pada tabel 3. Temperatur udara dan kelembaban udara di sekitar digester selama penelitian cukup tinggi kelembaban udara dan rendah pada temperatur lingkungannya, dikarenakan pelaksanaan penelitian dilakukan pada musim penghujan. Menurut Yuwono (2006), suhu di daerah tropis berkisar $25-35^{\circ} \mathrm{C}$ sudah cukup bagus. Namun suhu optimal dibutuhkan untuk membantu proses fermentasi berkisar $50-60^{\circ} \mathrm{C}$. Suhu optimal tersebut dapat dibantu dengan meletakkan tempat digester di lokasi yang terkena sinar matahari langsung. Apabila sinar matahari dimanfaatkan untuk menaikkan suhu maka gas metan yang dihasilkan semakin tinggi dan proses pembusukan berjalan lebih cepat.

\section{Kadar Air}

Tabel 4. Hasil Analisis Kandungan Kadar Air (\%) Sludge

\begin{tabular}{cccc}
\hline \hline Ulangan & \multicolumn{3}{c}{ Perlakuan } \\
\cline { 2 - 4 } & $\mathrm{P} 0$ & $\mathrm{P} 1$ & $\mathrm{P} 2$ \\
\hline I & 7,34 & 6,82 & 7,74 \\
II & 11,77 & 6,17 & 36,49 \\
III & 13,11 & 13,12 & 14,57 \\
\hline Rata-rata $^{\text {ns }}$ & $10,74 \pm 3,02^{\mathrm{a}}$ & $8,70 \pm 3,84^{\mathrm{a}}$ & $19,60 \pm 15^{\mathrm{a}}$ \\
\hline P0= 0\% eceng gondok, P1= 2,5\% eceng gondok, & gondok, ns= non signifikan \\
P2= 5\% eceng gondok
\end{tabular}

Menurut Yuwono (2006), bahwa fermentasi di dalam digester membutuhkan kadar air yang tinggi, yaitu $50 \%$ ke atas. Kadar air yang banyak pada proses anaerobik diperlukan bakteri untuk membentuk senyawasenyawa gas dan beraneka macam asam organik sehingga pengendapan sludge akan lebih cepat. Secara fisik, kadar air juga akan memudahkan proses penghancuran bahan organik dan mengurangi bau. Menurut Sutanto, (2006), bahwa makin rendah kandungan air, maka kualitas pupuk organik menjadi lebih baik.

\section{Kadar Bahan Organik (BO)}

Tabel 5. Hasil Analisis Kandungan Bahan Organik (\%) Sludge

\begin{tabular}{cccc}
\hline \hline Ulangan & \multicolumn{3}{c}{ Perlakuan } \\
\cline { 2 - 4 } & $\mathrm{P} 0$ & $\mathrm{P} 1$ & $\mathrm{P} 2$ \\
\hline I & 80,84 & 79,97 & 79,87 \\
II & 66,81 & 79,25 & 85,82 \\
Rata-rata $^{\text {ns }}$ & 70,31 & 69,37 & 72,93 \\
\hline P0= 0\% eceng gondok, P1= 2,5\% eceng gondok, & $76,19 \pm 5,92$ & $79,54 \pm 6,45$ \\
P2= 5\% eceng gondok, ns= non signifikan \\
\multicolumn{4}{c}{ Hasil yang diperoleh bila dilihat dari }
\end{tabular}

Tabel 5. tidak berbeda nyata antar perlakuan dalam penelitian. Namun, terdapat pengaruh 
interaksi perlakuan penambahan eceng gondok dan penggantian pengencer air dengan menggunakan limbah cair pengolahan tahu walaupun tidak berbeda nyata. Penambahan eceng gondok $5 \%$ terlihat adanya kenaikan kandungan bahan organik dalam sludge. Menurut Sutanto (2006), bahwa kandungan total bahan organik minimal $20 \%$. Keuntungan bahan organik terhadap kesuburan tanah adalah meningkatkan ketersediaan $\mathrm{P}$ dan $\mathrm{Fe}$ untuk tanaman. Di samping itu, bahan organik mampu meningkatkan kemampuan tanah mengikat lengas, memperbaiki struktur dan pengatusan tanah. Bahan organik juga memacu pertumbuhan dan perkembangan bakteri dan biota tanah lainnya. Menurut Harada et al (1993), standar kualitas pupuk organik memiliki kandungan bahan organik sebesar $>70 \%$.

Hasil penelitian kandungan bahan organik bila dibandingkan dengan literatur yang ada bahan organik hasil penelitian sudah cukup tinggi dan memenuhi standar kualitas pupuk organik.

\section{Nitrogen (N)}

Hasil yang diperoleh bila dilihat dari Tabel 6. tidak berbeda nyata antar perlakuan dalam penelitian. Namun, terdapat pengaruh interaksi perlakuan penambahan eceng gondok dan penggantian pengencer air dengan menggunakan limbah cair pengolahan tahu walaupun tidak berbeda nyata. Pada penambahan eceng gondok 2,5 dan $5 \%$ terlihat adanya kenaikan kandungan nitrogen dalam sludge.

Kandungan nitrogen kotoran ternak sapi adalah 0,3\%. Gulma air pada umumnya mengandung 16\%-21\% protein jenuh (berat kering), $80 \%$ nitrogen total dalam bentuk protein (Sutanto, 2005). Kadar protein yang terkandung dalam limbah cair tahu sebesar $1,72 \%$ (Nuraida et., al, 1996) dan kandungan protein eceng gondok sebesar 17,1\% (Anonimus, 2008). Nitrogen yang dihasilkan lebih rendah karena $\mathrm{N}$ telah dirombak oleh bakteri pengurai menjadi amonia dan menguap ke udara.

Tabel 6. Hasil Analisis Kandungan Nitrogen (\%) Sludge

\begin{tabular}{cccc}
\hline \hline Ulangan & \multicolumn{3}{c}{ Perlakuan } \\
\cline { 2 - 4 } & $\mathrm{P} 0$ & $\mathrm{P} 1$ & $\mathrm{P} 2$ \\
\hline $\mathrm{I}$ & 0,66 & 0,83 & 0,58 \\
II & 0,74 & 0,82 & 1,06 \\
III & 0,77 & 0,96 & 0,92 \\
\hline Rata-rata $^{\text {ns }}$ & $0,72 \pm 0,57$ & $0,87 \pm 0,78$ & $0,85 \pm 0,25$ \\
\hline P0 $=0 \%$ eceng gondok, $\mathrm{P} 1=2,5 \%$ eceng & gondok, \\
$\mathrm{P} 2=5 \%$ eceng gondok, ns= non signifikan
\end{tabular}

Fosfor (P)

Tabel 7. Hasil Analisis Kandungan Fosfor (\%) Sludge

\begin{tabular}{cccc}
\hline Ulangan & \multicolumn{3}{c}{ Perlakuan } \\
\cline { 2 - 4 } & $\mathrm{P} 0$ & $\mathrm{P} 1$ & $\mathrm{P} 2$ \\
\hline I & 0,09 & 0,10 & 0,11 \\
II & 0,33 & 0,12 & 0,73 \\
III & 0,35 & 0,50 & 0,30 \\
\hline Rata-rata $^{\text {ns }}$ & $0,25 \pm 0,14$ & $0,24 \pm 0,22$ & $0,38 \pm 0,32$ \\
\hline
\end{tabular}

$\mathrm{P} 0=0 \%$ eceng gondok, $\mathrm{P} 1=2,5 \%$ eceng gondok, $P 2=5 \%$ eceng gondok, ns $=$ non signifikan

Tabel 7. memperlihatkan bahwa hasil perlakuan P2 adalah yang tertinggi yaitu $0,38 \pm 0,32$ kemudian diikuti oleh perlakuan P0 sebesar 0,25 $\pm 0,14$ dan P1 0,24 $\pm 0,22$. Namun, terdapat pengaruh interaksi perlakuan penambahan eceng gondok dan penggantian pengencer air dengan menggunakan limbah cair pengolahan tahu walaupun tidak berbeda nyata. Pada penambahan eceng gondok 2,5 dan $5 \%$ terlihat adanya kenaikan kandungan phospor dalam sludge. Mikroba membutuhkan $P$ untuk metabolisme dan reproduksinya. Nitrogen dan fosfor dibutuhkan mikroba untuk metabolisme dan pertumbuhannya (Sutedjo, et al., 1991; Rynk, et al., 1992; dan Biddlestone, et al., 1994).

Menurut Harada et al., (1993), standar kualitas pupuk organik untuk kandungan fosfor adalah $>0,5 \%$. Apabila dibandingkan literatur yang ada dengan hasil penelitian yang diperoleh maka hasil penelitian yang diperoleh masih berada dalam standar kualitas pupuk organik. 
Agrisaintifika

Jurnal Ilmu-Ilmu Pertanian

Vol. 1, No. 1, 2017

Widyasmara \& Gamayanti, 2017

Kalium (K)

Tabel 8. Hasil Analisis Kandungan Kalium (\%)

Sludge

\begin{tabular}{lccc}
\hline \hline Ulangan & \multicolumn{3}{c}{ Perlakuan } \\
\cline { 2 - 4 } & $\mathrm{P} 0$ & $\mathrm{P} 1$ & $\mathrm{P} 2$ \\
\hline I & 0,24 & 0,34 & 0,34 \\
II & 0,42 & 0,38 & 0,98 \\
III & 0,43 & 0,61 & 0,63 \\
\hline Rata-rata $^{\text {ns }}$ & $0,36 \pm 0,11$ & $0,44 \pm 0,14$ & $0,65 \pm 0,32$ \\
\hline P0= 0\% eceng gondok, $\mathrm{P} 1=2,5 \%$ eceng \\
gondok, P2= 5\% eceng gondok, ns= non \\
signifikan
\end{tabular}

Tabel 8 memperlihatkan bahwa hasil perlakuan P2 adalah yang tertinggi yaitu $0,65 \pm 0,32$ kemudian diikuti oleh perlakuan $\mathrm{P} 1$ sebesar $0,44 \pm 0,14$ dan P0 0,36 $\pm 0,11$. Namun, terdapat peningkatan dibandingkan dengan sludge yang tidak terdapat eceng gondok, adanya peningkatan jumlah kandungan kalium walaupun hasil yang diperoleh tidak signifikan.

Menurut Harada et al., (1993), standar kualitas pupuk organik kandungan kalium adalah $>0,3 \%$. Bila dibandingkan literatur dengan hasil penelitian yang diperoleh maka hasil penelitian masih berada dalam standar kualitas pupuk organik.

\section{C/N Ratio}

Tabel 9. Hasil Analisis Kandungan $\mathrm{C} / \mathrm{N}$ ratio Sludge

\begin{tabular}{cccc}
\hline \hline Ulangan & \multicolumn{3}{c}{ Perlakuan } \\
\cline { 2 - 4 } & $\mathrm{P} 0$ & $\mathrm{P} 1$ & $\mathrm{P} 2$ \\
\hline I & 70,73 & 55,88 & 79,87 \\
II & 52,68 & 56,06 & 46,96 \\
III & 53,27 & 42,16 & 46,25 \\
\hline Rata- & $58,89 \pm 10,25$ & $51,37 \pm 7,97$ & $57,69 \pm 19,21$ \\
rata & & & \\
\hline P0 & & \\
P2 & & \\
P2 eceng gondok, P1= 2,5\% eceng gondok, &
\end{tabular}

Nisbah $\mathrm{C} / \mathrm{N}$ yang tinggi pada produk akhir menunjukkan mikroorganisme akan aktif memanfaatkan nitrogen untuk membentuk protein. Apabila produk pupuk organik dengan nisbah $\mathrm{C} / \mathrm{N}$ tinggi diaplikasikan ke dalam tanah maka mikroorganisme akan tumbuh dengan memanfaatkan $\mathrm{N}$-tersedia di tanah sehingga terjadi imobilisasi N. Penambahan bahan organik dengan nisbah $\mathrm{C} / \mathrm{N}$ tinggi mengakibatkan tanah mengalami perubahan imbangan $\mathrm{C}$ dan $\mathrm{N}$ dengan cepat, karena mikroorganisme tanah menyerang sisa pertanaman dan terjadi perkembangbiakan secara cepat (Sutanto, 2005).

Kebutuhan mikroorganisme akan karbon adalah sekitar 25 sampai 30 kali banyak $\mathrm{N}$ atau dengan kata lain rasio $\mathrm{C} / \mathrm{N}$ yang baik adalah 25 atau 30 , bila $\mathrm{N}$ terlalu tinggi maka populasi mikroorganisme rendah (Sihombing, 1997). Mikroba membutuhkan N 25-54 kali lebih banyak untuk merombak selulosa (Sutedjo, et al., 1991).

Kotoran sapi mengandung banyak $\mathrm{N}$ dan sedikit $\mathrm{C}$ sehingga $\mathrm{C}: \mathrm{N}$ ratio nya rendah. Sebaliknya eceng gondok memiliki kandungan $\mathrm{C} / \mathrm{N}$ sebesar 25 (Kariu dan Dixit,1984). Pencampuran keduanya menghasilkan C:N ratio gabungan antara kotoran sapi dan eceng gondok. Lebih lanjut, penambahan eceng gondok pada kotoran sapi menyebabkan peningkatan kandungan unsur $\mathrm{C}$ campuran bahan kompos. Akibatnya $\mathrm{C}: \mathrm{N}$ ratio meningkat. Mikroba menggunakan unsur $\mathrm{C}$ untuk mendapatkan energi dan memanfaatkan unsur $\mathrm{N}, \mathrm{P}$, dan $\mathrm{K}$ untuk pertumbuhan, metabolisme, dan reproduksinya, hal itu sesuai dengan pendapat Biddlestone, et al., (1994).

\section{KESIMPULAN}

Eceng gondok dapat digunakan sebagai bahan tambahan dalam campuran isisan digester dan limbah cair pengolahan tahu dapat digunakan sebagai pengencer bahan isian digester biogas. Perbedaan komposisi penambahan eceng gondok ke dalam isian digester tidak berpengaruh nyata terhadap kandungan unsur hara makro yang dihasilkan oleh digester biogas. Pupuk organik yang dihasilkan dengan perbandingan penambahan eceng gondok $5 \%(0,85 \% \mathrm{~N}, 0,38 \% \mathrm{P}, 0,65 \%$ K, 34,37\%. Komposisi pupuk organik rendah karena adanya dekomposisi oleh bakteri, tetapi kandungan unsur hara makro masih berada dalam kisaran standar sebagai pupuk organik. 
Agrisaintifika

Jurnal Ilmu-Ilmu Pertanian

Vol. 1, No. 1, 2017

Widyasmara \& Gamayanti, 2017

\section{DAFTAR PUSTAKA}

Anonimus. 2008. Pengolahan Hara Tanaman. Available at http/www.kmowledgebank.irri.org.pdf . Accesion date 19 April 2008.

Biddlestone, A.J., K.R. Gray, and K. Thayanithy. 1994. Composting and Reed Beds for Aerobic Treatment of Livestock Wastes. In Pollution in Livestock Production Systems. Edited by Ap Dewi, I., R.F.E. Axford, I. F. M. Marai, and H.M. Omed. Cab International. Wallingford, Oxon Ox10 8DE, UK. Pp. 345-360..

Don WS, Threes Emir dan Cherry Hadibroto. 2000. Tanaman Air. Penerbit PT Gramedia Pustaka Utama. Jakarta

Harada, Y.K., Tosaka, and M. Koshino. 1993. Quality of Compost Produced From Animal Waste. Japan Agriculture Research Quarterly.

Kaparaju, P., and I. Angelidaki. 2006. Effect of Temperature and Active Biogas Process on Passive Separation of Digested Manure. Journal Bioresource Technology. Volume 97 (2006):113-125.

Kirby, K.D. 1983. Anaerobic Digester and Their Application to Agriculture Residue Utilization. Australian Goverment Publishing Service. Canbera
Nuraida, L., S.H. Sihombing, dan S. fardiaz. 1996. Produksi Karatenoid Pada Limbah Cair Tahu, Air Kelapa dan Onggok oleh Kapang Neurospora sp. Bul. Teknol. Dan Industri Pangan. VII (1): 67-74

Rynk, R., M. van de Kamp, G.B. Wilson, T.L. Richard, J.J. Kolega, F. R. Gouin, L. Laliberty, Jr., D. Kay, D.W. Murphy, H.A.J. Hoitink, and W.F. Brinton. 1992. On-farm Composting Handbook. Editor R. Rynk. Northeast Regional Agricultural Engineering Service, U.S. Department of Agriculture. Ithaca, N.Y., Pp. 1-13.

Sihombing, D.T.H. 1997. Ilmu Ternak Babi. Gadjah Mada University Press. Yogyakarta

Supriyanto, Agus. 2001. Aplikasi Wastewater Sludge Untuk Proses Pengomposan Serbuk Gergaji. Available at http//www.goggle.com. Accesion date 27 November 2008.

Sutanto, R., 2005. Penerapan Pertanian Organik. Penerbit Kanisius. Yogyakarta

Sutedjo, M.M., A.G. Kartasapoetra, dan RD. S. Sastroatmodjo. 1991. Mikrobiologi Tanah. Cetakan pertama. Rineka Cipta. Jakarta. Hal. 1-105.

Wahyuni Sri, AMd, SE, MP. 2008. Biogas. Penerbit PT. Media Inovasi Transfer dan Penebar Swadaya. Jakarta

Yuwono, Dipo. 2006. Kompos. Penerbit Penebar Swadaya. Jakarta 